\title{
Elites, political elites and social change in modern societies ${ }^{1}$
}

\author{
Luis Garrido Vergara*
}

\begin{abstract}
Resumen
Los estudios académicos acerca de las élites políticas poseen una vibrante historia reciente. El objetivo aquí es proveer un resumen selectivo de esa historia, enfocándose en la importancia de la distinción social y en las teorías de la estructura de poder como el marco teórico para comprender la influencia de las élites políticas en el cambio social. Dado que nuevas perspectivas y preocupaciones han surgido en este campo, la organización de este artículo no es completamente cronológica. Aunque puedan haberse ignorado muchas contribuciones relevantes, la intención aquí es brindar algún sentido de la riqueza e importancia de lo que han logrado los académicos acerca de la relación entre élites y representación, los vínculos entre élites, democracia y cambio social y las teorías de la estructura de poder. En este artículo también se estudia hasta qué grado la introducción de una nueva metodología de investigación por parte de la teoría de la dominación de clase de Domhoff abrió una nueva perspectiva en los estudios sobre las élites. Finalmente, se presentan una estrategia de investigación para las élites y dos conclusiones principales.
\end{abstract}

Palabras clave: Élites políticas - cambio social - estructura de poder - representación.

\begin{abstract}
Scholarly studies of elites and political elites have a vibrant recent history. My aim here is to provide a selective summary of that history, focusing on the importance of social distinction and the theories of power structure as a theoretical background for understanding the influence of political elites in social change. Since new insights and concerns have emerged in this field, the organization of this essay is not entirely chronological. Even though I may have ignored many relevant contributions, my hope here is to provide some sense of the richness and significance of what have been accomplished by scholars regarding the relationship among elites and representation, the links between elites, democracy and social change and the theories of power structure. In this paper I also study the extent to which the introduction of a new research method by Domhoffian class domination theory opened a new insight in élite studies. Finally, an élite research strategy and two main conclusions are presented subsequently.
\end{abstract}

Keywords: Political elites - social change - power structure - representation.

1 Quisiera agradecer a David Lehmann (University of Cambridge), Patricio Navia (New York University) y a Juan Carlos Lerda (Universidad de Chile) por todos sus útiles comentarios y consejos, así como también a los dos evaluadores anónimos por sus sugerencias. No obstante ello, toda la responsabilidad por el artículo es mía.

* $\quad$ PhD (C) en Sociología, University of Cambridge. Sociólogo y Magíster en Gestión y Políticas Públicas, Universidad de Chile. Correo electrónico: Ig424@cam.ac.uk 


\section{INTRODUCTION}

\subsection{Elites and social distinction}

An élite is a selected and small group of citizens and/or organizations that controls a large amount of power. Based on the social distinction with regard to other groups of lower strata (Daloz, 2010), most of these selected groups are constantly searching differentiation as well as separation from the rest of society. Normally the concept of élite is used to analyze the groups that either control or are situated at the top of societies. The creation of an élite is also the result of their evolution throughout the history of humanity. Several groups are constantly seeking different social resources in order to define their specificity.

Elites and social distinction have a long vibrant history. Since the beginning of the Greek society and the Roman Empire social status has been relevant. Whereas Greek society was mainly broken up between free people and slaves, the social structure of ancient Rome was based on property, wealth, citizenship and freedom, with a significant importance of heredity. Even though in both societies social stratification existed, in the case of the latter social status was established through objective norms (Grantt, 1978). Later on, in both Middle Ages and in Modern Times this form of distinction through the social status prevailed, and probably it could be considered as the main principle of social organization currently. Research in social sciences has emphasized the tendency of elites to persist and reproduce their power over time at "political and economic levels, potentially undermining the effectiveness of institutional reforms. For instance, one specific form of élite persistence is illustrated by the existence of dynasties, a particular form of élite persistence in which a single or few family groups monopolize either political and/or economic power" (Querubin, 2011: 2).

Numerous scholars have studied the élite distinction. Through the use of a wide range of both, qualitative and quantitative variables such as social status, social stratification, and local culture, amongst others, they have developed theories about its evolution and their performances in modern societies. However, a main issue has emerged with regard to the extrapolation of their predictive capabilities: "One serious problem with this topic is that social theorists have all too often been more interested in finding confirmation for their respective grand theories than in considering the various realities of distinction comparatively. Whenever they have brought empirical evidence to support their position, the main shortcoming has been extrapolation: that is the claim to provide sociological Laws on the grounds of one particular case during a given period" (Daloz, 2007: 2). According to Daloz, this "issue" has prevailed from several classical theoreticians such as Spencer, Tarde, Veblen, Simmel, Weber and Sombart to major subsequent contributions from Neo-Marxism, Functionalism and post-modern perspectives that have analyzed social distinction and emulation (Daloz, 2010). However, when sociological research started to connect social distinction with the creation of elites, a new theoretical background emerged. Pierre Bourdieu's Distinction (1984) is probably one of the first and most important researches focused on the relation among elites and social distinction. Under the premise of "no judgement of taste is innocent", Bourdieu attempted to analyze French bourgeoisie, its tastes and preferences. He performed 
a vast ethnographic study of contemporary France through the analysis of bourgeois mind. A remarkable quote, which resumes one of the main principles of distinction in social sciences according to Bourdieu's ideas, is the following:

"Principles of division, inextricably logical and sociological, function within and for the
purposes of the struggle between social groups; in producing concepts, they produce
groups, the very groups which produce the principles and the groups against which they are
produced. What is at stake in the struggles about the meaning of the social world is power
over the classificatory schemes and systems which are the basis of the representations of
the groups and therefore of their mobilization and demobilization: the evocative power of
an utterance which puts things in a different light (as happens, for example, when a single
word, such as 'paternalism', changes the whole experience of a social relationship) or which
modifies the schemes of perception, shows something else, other properties, previously
unnoticed or relegated to the background (such as common interests hitherto masked
by ethnic or national differences); a separative power, a distinction, diacrisis, discretio,
drawing discrete units out of indivisible continuity, difference out of the undifferentiated"
(Bourdieu, 1984: 479).

One of the most important contributions of this theory is the idea that social class plays a significant role in the construction of a personal identity (i.e. a person's interests). Thus, as social classes are in permanent interaction during the daily life, several "social differences" are reinforced such as the taste, which according to Bourdieu is an "aesthetic" value defined by the ruling class. These social uses of communication (Bourdieu, 1965: 1991) are also related with the relation between elites and mass (Hartmann, 2007). However, distinction is also related with other social uses and resources as power in politics and wealth in economics.

\subsection{Political elites and social class}

A political élite is a group of people, corporations, political parties and/or any other kind of civil society organization who manage and organize government and all the manifestations of political power: "elites may defined as persons who, by virtue of their strategic locations in large or otherwise pivotal organizations and movements, are able to affect political outcomes regularly and substantially" (Higley, 2008: 3). Social class and elites are linked. Scholars have shown that one of the main aspects in the conformation of elites is given by social class patterns (Moore, 1966; Huckfeldt and Kohfeld, 1989; Lane, 2007). The most influential perspectives in sociological research historically have been provided from Marxism and Functionalism (Wright, 2005). Max Weber's sociology developed a strong theoretical framework for understanding the connection between social strata and political action in modern societies. Influenced by Marx's ideas, Weber created a theory of social stratification arguing that power could take a variety of forms in the social interplay. He emphasized the idea that besides class, there were other sources of power in modern societies, such as the status, which was defined by consumption (Weber, 1946, 1964, 1978).

Since the 1970s, a wide range of sociological empirical research has mainly focused on explaining social determinants on ruling elites. Considering topics such as social origins, type 
of education, socioeconomic status, social and political capital among others, several scholars have analyzed what factors explain the creation of elites as well as how they evolve in time. The main principle of this kind of research was the Weberian sociological concept of "elective affinity" (Weber, 1958), which define the association between certain variables defined by beliefs, actions, and/or unknowing or unexpected consequences of social action (Howe, 1978).

Why is important to consider this concept of elective affinity? There is a link between the Bourdieuian theory of distinction and of the social uses of values and this Weberian concept. As political elites are constantly struggling for power and also they share social origins and interests, they are different since their origins.

FIGURE 1

Political elites and mass

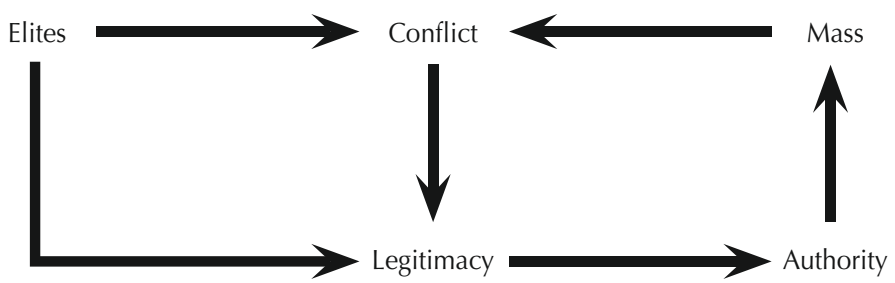

Source: Own elaboration.

As showed in Figure 1, political elites are constantly controlling power resources over the mass. The elites have power over the state, the civil organization of political power. Even though they could have conflicts with the mass, which certainly can affect political decisions from "top down" to "bottom up" (Easterly, 2008), the possession of multiples forms of capital (social, cultural, economic, politic, among others) allows to elites to ensure their social reproduction as well as the cultural reproduction of the ruling class.

\section{THE FOUNDATION OF A FIELD OF STUDY}

In political sociology several have studied the connection between elites and the power structure. Since the beginning of nineteenth century is possible to find research that attempted to analyze the social dynamics of power structure, with regard to the behavior of social groups as well as concerning the study of the relationship between individual interactions and group level behaviors. This part starts with the classical question: "who governs?" stated by Dahl in the 70 s and then explores the main contributions that let the foundation of a field of study.

\subsection{Who governs?}

Who governs? This classical question stated by Robert Dahl (Dahl, 1961, 1979) and its relation with the concept of elites have been widely studied and vigorously debated since the 
nineteenth century. Pareto (1901) was one of the first researchers to perform a sociopolitical analysis of elites based on his study of the political role played by aristocracy in Italian society (Rossides, 1998: 23). Interested in explaining the social factors that affect human action, Pareto developed one of the main arguments of the Social Cycle Theory, which pointed out that the evolution of society and human history generally repeat themselves in cycles. Notwithstanding that this theory recognizes the idea of social progress, this perspective contrasted with the theory of social evolutionism, which viewed the progress of society and human history as a permanent progression in some new, following unique directions and/ or patterns (Turchin, 2003).

Pareto was one of the first sociologists to define the concept of ruling elites (Pareto, 1991; Zuckerman, 1977), which consisted in a small and selected political group of people with superior personal qualities that governed the "mass of society", which was all the rest of individuals who were considered by Pareto as unintelligent, irrational and therefore, poorly organized. Hence, under these conditions it was completely possible for the ruling élite to manipulate them through political propaganda "carefully used" (Pareto, 1991).

Mosca (1939) claimed that the conformation of elites was strictly determined by the social structure. The ruling élite was formed by the members of the upper class, which was composed of the wealthiest members of society, who also wielded the greatest political power (Mosca, 1939; Zuckerman, 1977; Bottomore, 1993). Michels (1915), after analyzing German and Italian political systems, concluded that political parties, including those considered socialist, cannot be democratic due to the fact that after being created they inevitably would tend to transform themselves into bureaucratic oligarchies (Michels, 2001). Following Max Weber, Michels claimed that the main objective of a democracy, which he defined as a society without elites, was impossible to achieve because this form of government was based on some form of acknowledgment from the ruling elite. Thus, as in modern societies the oligarchy was the élite that rules due to its power, this form of political domination was inevitable (Michels, 2001). Michels developed the theory of "iron law of oligarchy", his biggest contribution to sociopolitical thought (Wright Mills, 1956; Putnam, 1976; Zuckerman, 1977; Bottomore, 1993). These contributions laid the foundation for a field of study in political sociology.

Hunter (1953) examined the power relationships focused on a group of small communities in the U.S. (at a micro level perspective). Hunter studied the structural and functional uses of power as well as the definition of hierarchies in social networks. His sociopolitical analysis of power based on "mapping" social relations became a significant resource for studying corporate elites in later years (Schwartz, 1987). According to Domhoff (1967), this was the starting point for the systematic study of power within sociology.

\subsection{Elites and political representation}

Political elites and representation are often related due to the fact that these groups are constantly searching to control government. In modern democracies, political authorities have to represent the interests of citizens. For winning elections, politicians must succeed in 
convincing electors: "political life is not merely the making of arbitrary choices, nor merely the resultant of bargaining between separate, private wants. It is always a combination of bargaining and compromise where there are irresolute and conflicting commitments and common deliberation about public policy, to which facts and rational arguments are relevant" (Pitkin, 1967: 212). Politicians are frequently dealing between the "mandate" of the post and the interests of people that represent. Currently, these interests are expressed by public opinion polls.

Political representation in most Western democracies depends of political parties. The functioning of democratic systems is determined not only by either for the action of citizens or the performance of political system, but also by the behavior of political actors. Decision-makers in public institutions are political elites and they operate through political parties. What is in permanent tension in current societies is the relationship among power, conflict and authority (Lasswell and Kaplan, 1950). Political elites have to deal with power institutions and "shape" the political system. In some cases the elites elaborate strong rules in order to maintain their power avoiding political competition. In other cases, the elites must compete among them and/or with others citizens. Thus, is society controlled by a small group of insiders? This is the paradox of political elites: between political representation and the maximization of their own interests.

\subsection{Elites, democracy and social change}

What does social science have to say about social change? Social sciences have developed a wide range of theoretical framework as well as empirical methods for studying the evolution of modern societies. Among them, political science and sociology have made important contributions concerning the analysis of power, conflict and authority. At the empirical level, a great volume of this line of investigation has focused on the "social basis" of democracy and consensus. Using social stratification categories many scholars have studied the dynamics of voting and mass electorates as well as the performance of political parties.

Regarding the relationship between democratic consolidation and social change, Morlino (1989) argued that stability in democracies was determined by the behavior of the political elites and non-political elites, i.e. the degree of commitment of elites with the maintenance of the political regime of representative democracy. A crucial theoretical contribution to the concept of "consolidation of democracy" came up from Linz and Stepan (1996), who claimed that modern consolidated democracies do necessarily require the acceptance of a series of rules, institutions and regulations, socially and politically constructed and accepted, which introduced the tension among political economy and democratic theory, because not always political and economic incentives are socially accepted.

\subsection{Elites and power structure}

The main issue regarding the link between democratic consolidation and social change is how societies define its power structure. Most social scientists consider that power can be 
studied either as collective power, which is the capacity to perform effectively in pursuing its common goals, or regarding the ability of a group (élite) within a community to be successful in conflicts with its rivals. Both dimensions are intertwined, but the second prevails for studying political elites.

The theoretical starting point for elites and power structure research is that in modern societies the basis of power, authority and conflict is in the human organizations (Domhoff, 2006). As they are conformed to accomplish a set of purposes, they often develop rules, specific roles and routines. They frequently must compete among them. In political sociology five theories have attempted -from different perspectives and models- to explain and to analyze power structure (Mann, 1986; Hall and Schroeder, 2005; Domhoff, 2005).

As indicated in Figure 2, five theories have attempted to explain and to analyze power structure in political sociology: Pluralism, State Autonomy Theory, Elite Theory, Marxism and the Class-Domination Theory. Pluralism considers that in modern societies

FIGURE 2

Theories of power structure

\begin{tabular}{|l|l|l|l|}
\hline \multicolumn{1}{|c|}{ THEORY } & \multicolumn{1}{|c|}{$\begin{array}{c}\text { THEORETICAL } \\
\text { BACKGROUND }\end{array}$} & THEORETICAL PERSPECTIVE & \multicolumn{1}{|c|}{$\begin{array}{c}\text { PRINCIPAL } \\
\text { EXPONENTS }\end{array}$} \\
\hline Pluralism & $\begin{array}{l}\text { General theory of } \\
\text { society }\end{array}$ & Multiple centers of power & $\begin{array}{l}\text { R. Dahl and S.M. } \\
\text { Lipset }\end{array}$ \\
\hline State Autonomy & $\begin{array}{l}\text { Theory of government as } \\
\text { an independent force }\end{array}$ & Government as power center & Theda Skocpol \\
\hline Elite Theory & $\begin{array}{l}\text { Theory of organizations } \\
\text { The leaders of big } \\
\text { organizations inevitably } \\
\text { dominate all large-scale } \\
\text { societies }\end{array}$ & Thomas Dye \\
\hline $\begin{array}{l}\text { Marxism } \\
\text { historical materialism } \\
\text { Domination } \\
\text { Poweory }\end{array}$ & $\begin{array}{l}\text { Theory of domination } \\
\text { and power network }\end{array}$ & $\begin{array}{l}\text { Class domination } \\
\text { Domination by the few does } \\
\text { not mean complete control, } \\
\text { but rather the ability to set } \\
\text { the terms under which other } \\
\text { groups and classes must } \\
\text { operate. }\end{array}$ & $\begin{array}{l}\text { Mills, G. William } \\
\text { Domhoff }\end{array}$ \\
\hline $\begin{array}{l}\text { Charles, Wright } \\
\text { Gerald Cohen, John } \\
\text { Roemer, Jon Elster, } \\
\text { Erik Olin Wright }\end{array}$ \\
\hline
\end{tabular}

Source: Own elaboration. 
there is a wide range of groups and individuals that concentrate power. Conversely, the State Autonomy Theory argues that the State is the main organization that holds political power. Closely to Pluralism, the Elite Theory claims that global and local societies are under the control of big organizations such as the state and/or big enterprises, and thus their leaders are constantly deciding about their future. Following the Theory of Historical Materialism, Marxism categorizes societies regarding the concept of social class: each individual has a "position" in the means of production. Finally, Class Domination Theory analyzes power structure concerning the different positions of domination of each group in the social order. It analyzes the social networks with regard to how the power is wielded (who benefits?, who governs? and who wins?). More than dominant classes, this perspective explains how different groups compete for controlling the society and how this affects social evolution.

Unlike State Autonomy and Marxist theories, Class Domination Theory is not focused in only a single organizational basis of power (the political network for the State Autonomy theorists and the economy for the Marxists). Besides, unlike the Elite Theory, Class Domination Theory does not consider that domination by a few leaders means complete control of the society, but rather the ability to set the terms under which other groups and classes must operate.

Pluralism could be considered similar to Class Domination Theory. However, there is an important difference among them with regard to the definition of power structure. Whereas Pluralism tends to relativism arguing that instead of hierarchies there are multiple centers of power, Class Domination Theory claims that control and authority inevitability provoke a power structure based on domination.

Following this approach many scholars have been studied political elites at both the theoretical and the empirical levels. Several authors have also examined the social structures to compare the influence of the elites across the political system and the rest of the society. In his controversial book Who Rules America? (1967) Domhoff analyzed the power structure in the U.S. regarding local and national decision-making networks. Following Hunter's ideas (1953) Domhoff pointed out that more than "group struggles" (Davis, 2000) there was an economic upper élite that concentrated the political power in the United States (Domhoff, 1967). In later research, Domhoff explained two essential concepts amidst the upper élite's body. On one side there was the power or ruling elite, which was composed for the leaders of high-level organizations, and on the other side, the rest of the members who do not do the ruling (Domhoff, 1990, 1996, 2002, 2003). This was a significant contribution to the study of political elites in terms of understanding their composition, their ways of action and their spheres of influence on a society.

Domhoff research showed that Class-Domination Theory has several advantages for explaining political elites regarding their social interactions and performance. As political elites are often conformed by several networks, this theoretical perspective is effective in analyzing their performance and thus the policy planning network. 


\subsection{How to do power structure research?}

One of the biggest issues of élite research is expressed in its dubious generalizations and extrapolations (Daloz, 2010, 2007). In the literature of élite research there is a tendency towards generalization. Through "universal" principles, the idea is to reproduce theoretical schemes on different societies. Nevertheless, the particularities of each society do not allow scholars to reproduce their theoretical frameworks completely. This reason explains why Daloz $(2010,2007)$ claimed about the "paradox of Grand Theories" in élite research.

Concerning this problem, Domhoff (2012) developed a strategy for doing power structure research. He argued that the first step is based on the identification of a power structure. Then, through the use of two analytical methods, the objective is to understand, describe and define the groups that control power.

Figure 3 shows a diagram that explains how network and content analysis are connected for explaining power structure. In sociology the social network analysis has emerged as a key technique to connote complex sets of relationships at different levels from interpersonal to organizational relations. Domhoff argues that identifying membership in networks is very important to define and describe power groups. After that, "once the membership networks have been established, there are many other types of links that might be analyzed, such as kinship ties or flows of information between organizations. One of the most important of these other types of links concerns the size and direction of money flows in the network" (Domhoff, 2012).

As a technique, content analysis is a methodology that is focused on the understanding of human communication including all its manifestations and properties in a context including understanding the meaning of language, words and phrases. Content analysis has emerged

FIGURE 3

Power structure research

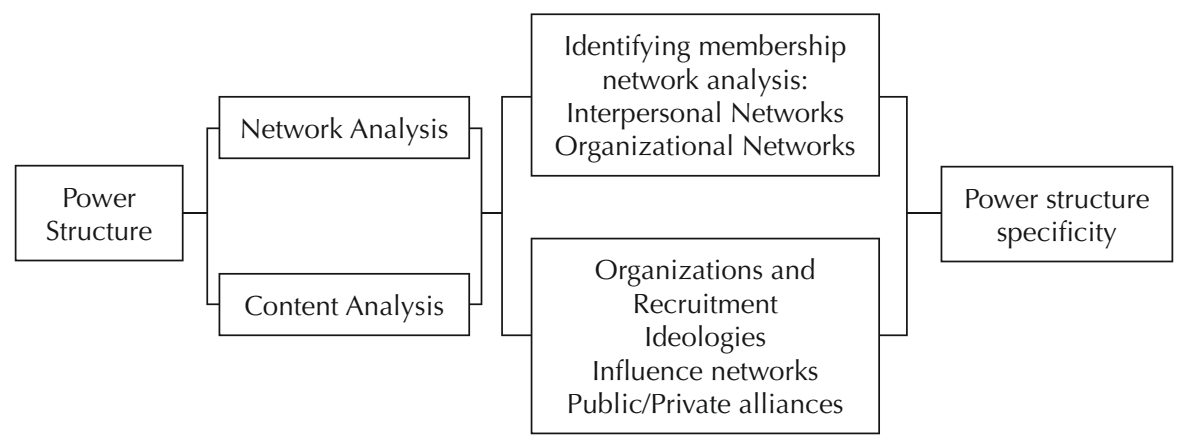

Source: Own elaboration based on Domhoff (2012). 
as a complementary technique aimed at analyzing the communications amongst networks at interpersonal and organizational levels. The objective is to define what type of individuals and organizations are participating. How the elites develop their recruitment strategies, what kind of ideologies are involved, what are their influences and what are their public-private alliances, among others. This method is essential in providing specific characteristics to the power structure as well the elites that are involved. From these empirical findings Domhoff argues that élite theory can be performed according to local level. This perspective opens a new insight for understanding the elites from macro to micro levels.

\section{III. “WEALTH MATTERS": RECENT PERSPECTIVES AND RESEARCH}

\subsection{Empirical studies about elites: from social capital to its connection with politics}

Bourdieu's sociological theory has had an important influence on the empirical studies of governmental elites (Joignant, 2009). His concept of "social capital" (Bourdieu, 1979, $1980,1989)$ has undoubtedly provided an empirical strategy for measuring both social relations and levels of influence. Following this perspective, several scholars have studied a wide range of links in order to define, describe and explain the performance of "power networks" in societies. Gaxie (1983) studied the social factors determining the governmental career during the fifth republic in France from 1959 to 1981. He concluded that some of the political networks were created following social determinants as either familial, social class and/or social status. A similar conclusion came from Hughes (1993), who analyzed the conformation of power networks in western societies during 1880-1930 because of the developing of electricity. Elites and social groups were determined by a new coordination between technology and politics (Hughes, 1993: 175), which became in an essential resource in modern societies. Hughes compared this with the impact of manorialism on medieval society (Hughes, 1993).

Regarding the relation among elites, politics and economic power, Kadushin (1995) investigated the French financial élite. One of his relevant findings was that most of the financial elites were linked by significant ties of friendship, which certainly allow them to construct and maintain a certain level of similarity (Suleiman and Mendras, 1995). Mathiot and Sawicki (1999), analyzing the performance of the members of the Socialist Cabinets in France, concluded that this principle of homogeneity of the trajectories of the elite's members can lead to homogeneous behavior in public action and other social spheres, considering that elites are linked to a wide range of them (Mathiot and Sawicki, 1999). However, elites can be faced among them when their interests come into conflict, especially when political and economic elites are confronted, as Garrigou (2001) concluded regarding the French case.

Finally, Genieys (2005) attempted to explain the impact of the elite's performance on the development in France. Distinguishing among professionals and politicians "by instinct", he analyzed the French elitism according to three perspectives: the comparative, the historical 
and the policy-making. Genieys concluded that in order to improve empirical observation in the study of élite action it was necessary to study the decision-making process. He argued that during this phase of public policy process the 'selected groups' that act could be identified. Genieys claimed that through this method it was possible to explain how new power elites were formed.

Contrary to Bourdieu's perspective, Putman analyzed of how capital social generates collective goods through the conformation of "power networks" (Putnam, 1977; Li, 2005). Putnam's research was one of the first in analyzing the relationship among elites and technocracy. He studied how the elites were transformed after industrial revolution and how technocracy became a significant source for them, similar to Hughes' research (1993). However Putnam was beyond arguing that technocracy allowed the advent of a new élite of specialist, which later were called as technocrats (Xiao, 2003).

Since the beginning of the 1990s, several scholars studied the links between elites regarding political regimes and political stability. This perspective has been useful for studying political transitions, most of all, regarding the cases of the countries from East Europe and Latin America. According to this theoretical viewpoint, the basic condition for having a solid and stable regime is the "unity" of the different elites, which must be expressed mandatorily at institutional level. In other words, democratic consolidation requires the achievement of élite's "consensual unity", which is an agreement between all politically important elites on the meaning of existing democratic institutions as well as the respect for democratic "rulesof-the-game", coupled with increased "structural integration" among those elites (Vanden and Prevost, 2002; Higley and Gunther, 1991).

In Latin America, one of the foremost origins of the research field based on élite's performance as well as its political influence was with Lipset (1959, 1960; Lipset and Solari, 1967). His research was focused on the role of the elites in the processes of democratization and economic development. Afterwards, this topic has been widely studied by several scholars (e.g. Przeworski et al., 1997; O'Donnell and Schmitter, 1986; Higley and Gunther, 1991; Mainwaring, Brinks and Perez-Linan, 2001).

Regarding Latin American case, after studying several democratic transitions and breakdowns, Higley and Burton suggested that "all democratic transitions are the products of élite choices" (1989: 22). In the continent, the theory of elite's settlement was conceived as an alternative to populism (Skocpol, 1979). Several scholars argued that elites were the basis for having a democratic consolidation in the region (O'Donnell and Schmitter, 1986; Higley and Pakulski, 2000). Yet, as democratization processes were highly influenced by Washington consensus recommendations, several reforms were led by specialists and technocrats, a constituted a selected group of the élite, as shown by Dézalay and Garth (2002).

Finally, Khan (2012) analyzes how privilege is determinant in the creation of elites in The U.S. society. He claims that current élite think of themselves as far more individualized, considering that their position is the result of what they have done. They deemphasize refined tastes and "who you know" and instead highlight how you act in and approach the world. 


\subsection{Empirical studies about elites in Chile}

In Chile, the study of elites has been influenced by qualitative methods. From the creation of biographies through prosopographical methods (Levi, 1989; Daviet-Vincent, 2004) to attempts to investigate objectively the patterns of cause and effect that determine historical events, a wide range of scholars have tried to define, describe and explain these groups with regard to either their structure or their performance, at micro or macro level.

Through the analysis of personal biographies, De Ramón (1999) studied Executive, Legislative and Judicial Powers in Chile. From each personal story of their selected members, he developed a "collective" history of Chilean State. However, this research is mainly descriptive. More than explain, it created a "collective" story.

Dézalay and Garth, (2002) developed a research similar in methods, but aimed at finding patterns of the élite that led democratization. They found empirical evidence concerning the role played by the new technocrats in Chilean political elite, who were called as technopols (Dominguez, 1997; Joignant 2011), individuals with both higher political capacity as well as with higher academic credentials and professional quality. Silva $(1991,2008)$ analyzed the influence of technocrats in the transformation of Chilean society. Silva believed that a technocratic elite dissident of Pinochet' dictatorship played a significant role in settling a political transition in Chile. Moreover, these same elites have created Think-Tanks, which have allowed them to maintain a strong influence in political and public life.

Gazmuri (2001) essayed to identify patterns to describe and define the origin and evolution of Chilean elites from 1930 to 1999. One of the main contributions of this research is the analysis of the educational and professional trajectories of the political élite. Gazmuri concluded that most of the politicians were formed at the Universidad de Chile until 1930s decade. Since that date both the Universidad Católica and the Universidad de Chile have formed the local élite. In 2003, Joignant and Navia analyzed the Union Demócrata Independiente (UDI), which is the biggest right political party in Chile, in terms of socialization, political competition and electoral growth. They argued that the UDI was a political party inspired in a highly conservative structure of values inspired from the military dictatorship headed by Pinochet and from the "Opus Dei", an institution of the Catholic Church. Following a similar perspective, Barozet and Aubry (2005) studied the relationship among the institutional structure with the electoral performance of Renovación Nacional (RN), the second biggest right political party in Chile.

Thumala (2008) analyzed the catholic-economic élite in Chile, observing their networks of influence in several spheres of society. This research accomplished empirical evidence of the economic, political and cultural influence of Christianity in Chile. Contrary to the Bourdieusian theory of distinction, the author argues that the religiously inspired ideals of self-discipline and ethical action cannot be understood entirely if they are seen as guided by interests. She sustains that individuals might pursue religious aims if they value them in themselves and have true commitments to religious norms. 
Cordero (2005) studied the social composition of the Chamber of Deputies of Chile. Considering a period from 1961 to 2010 this is one of the most current studies regarding this topic. This research had two relevant findings: first, the incumbent members of Parliament have historically evolved favorably in their education and also in their professional trajectories, notably between 2006 and 2010. Second, the common patterns of socialization -mainly defined for their educational political trajectories- and the higher rates of time of permanency as incumbent, allow the consolidation of a parliamentary élite. Finally, the author suggests that with the increasing of women and local representation in the Parliament, its role will be more effective and innovative in Chilean society.

Chilean democracy certainly has received a heritage from Pinochet. Several economists educated in Chicago, known as "Chicago Boys", implemented several reforms during dictatorship that prevailed after political transitions. Some scholars have concluded that the "Chilean model" inevitably has had an important legacy from Pinochet, above all regarding the economic development. Valdés (1995) and Silva (1991) have analyzed the consequences of this group after democratic transition. On the other hand, Markoff and Montecinos (1993) analyzed how this group was born influenced for one sector of the political élite pro-Pinochet and for the support from United States.

One of the most significant studies about elites and power in Chile was in 2004, when the United Nations Development Programme (UNDP) (2004) analyzed and defined four types of elites in Chilean society: political, economic, social and symbolic or cultural. Among their findings, UNDP specialist concluded that Chilean elites are dealing with a dichotomy between following the modernity in economic development -success in innovating- and being traditional and conservatives in their social values and orientations, which is expressed in maintaining and defending traditional institutions as family and religious education, basically inspired in Christianity. These categories will be used in this research.

Espinoza (2010) analyzed the social basis of power dynamics in the Chilean political élite regarding the personal networks of Chilean parliamentarians from 1990 to 2005. The main argument of this article is that a similar social background of members of Parliament joined with a common social interaction reduces the ideological differences, which determines the stability of political system. He argues in favor of elites as groups with members in positions of formal authority, social prestige and participation in the process of decision-making. The empirical results of this study support the theory of domination as "power that is structured into stable and enduring relations of control" (Scott, 2008: 31).

Finally, following an economic perspective Solimano (2012) analyzed Chile's political economy since the political transition with regard to the country's attempt to build a market society in a highly inegalitarian society. His research provides a historical background of Chilean economy and society and discusses the cultural effects of the imposition of free markets, the macroeconomic and growth performance of the 1990s and 2000s, and the social record of privatization of education, health, and social security. It also describes how these new policies promoted the growing concentration of economic power among small groups of elites in Chile after the departure of the Pinochet regime. 


\section{ELITES AS AN OBJECT OF STUDY}

Elite research is not as developed as other areas of political sociology inquiry. Figure 4 shows a proposal of a research strategy for élite studies. It takes into account both Bourdieusian perspectives about social distinction as well as Domhoffian insight based on class domination theory.

In this Figure three phases are settled: identifying, analyzing and finally, defining. There are four dimensions of analysis:

The evolution of society: Basically is defined by the local history in which elites are situated. This dimension allows describing and defining the circumstances and determinants in the creation of an élite.

Institutions, social structure and social capital: This dimension also entails an historical perspective. In sociological terms, the objective is mainly defined by the understanding of socio-structural context that has an effect on the élite performances. Institutions, understood as the formal and informal rules and social capital, which is the expected economic, political, cultural or any other social benefits derived from the preferential treatment and cooperation between individuals and groups, are essential in encouraging the creation of these groups.

FIGURE 4

Elites as an object of study: Proposal of a research strategy

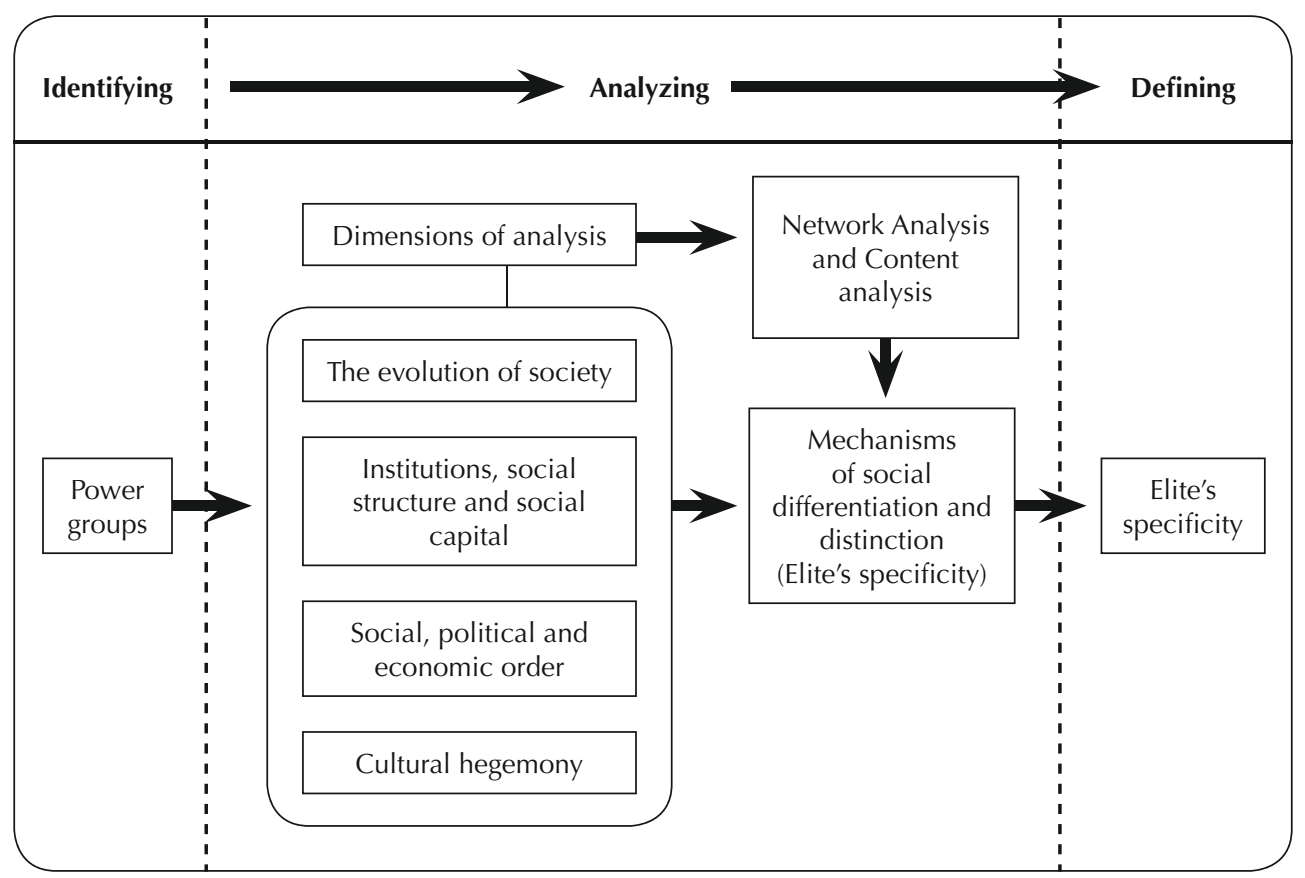

Source: Own elaboration. 
Social, political and economic order: From a socio-historic perspective, this is the analysis of the manner in which different types of power can be distributed in a society. This is essential in the definition of the relationship among the elites and the mass, and also in the relationship between conflict, authority and legitimacy in the social order.

Cultural hegemony: This dimension is defined mainly to the system of social relations and expression of local values, which have been objectified throughout the history. In other words, this is the local construction of reality that determines and defines social interaction (Berger and Luckmann, 1966).

After defining potential élite, these four dimensions are significant for conducting both network and content analysis because they allow researcher to identify the mechanisms of social differentiation and distinction of the élite (the élite's specificity). This model does not pretend to be universal. The objective is to provide a strategy for using élite theories to the local level in each society.

\section{CONCLUDING REMARKS}

1. This article examined scholarly studies of political elites focusing on the importance of the social distinction theory and also of the class-domination theory as a theoretical background for understanding elites, political elites and social change. Class-Domination Theory is an important landmark in political sociology. Bearing in mind the difficulties of understanding human action in social sciences, Domhoff research provides a theoretical background and a method based in the idea that domination by the few does not mean complete control, but rather the ability to set the terms under which other groups and classes must operate. This principle has allowed the analysis of élite's performance through the policy network, which certainly contributes for understanding the influence of political dynamics in social change.

2. Elite research is not as developed as other areas of political sociology inquiry. Social distinction and power structure theories are essential for identifying which groups are élite and which are not. When the composition of the power élite is clearly stated, it is possible to show how the social relations are defined considering the interest of the upper class and from the corporate community. Finally, as the very phrase "power structure" suggests, it is extremely difficult to change power arrangements, even in those countries where citizens have won the right of vote and have reached high levels of public freedom of expression.

\section{BIBLIOGRAFÍA}

Barozet, E. y M. Aubry (2005): “De las reformas internas a las candidatura presidencial autónoma: los nuevos caminos institucionales de Renovación Nacional", Política, 45, pp. 165-196.

Berger, P. L. y T. Luckmann (1966): Social construction of reality: a treatise in the sociology of knowledge, Anchor Books, Garden City, NY.

Bottomore, T. (1993): Elites and society (Second edition), Routledge, London. 
Bourdieu (1979): La distinction. Critique sociale du jugement, Ed. De Minuit, Paris.

(1980): Le sens pratique, Ed. De Minuit, Paris.

(1984): Distinction. A social critique of the judgement of taste, Harvard University Press, Cambridge, Mass.

(1986): "The forms of capital", en J. Westport (ed.): Handbook of theory and research for the sociology of education, Greenwood, New York, pp. 214-258.

(1989): La noblesse d'Etat. Grandes écoles et esprit de corps, Ed. De Minuit, Paris.

(1991): Language and symbolic power, Harvard University Press, Cambridge, Mass.

Bourdieu, P., R. Castel, L. Boltanski y J. C. Chamboredon (1965): Un art moyen: essai sur les usages sociaux de la photographie, Ed. De Minuit, Paris.

Cordero, R. (2005): “La composición social de la nueva Cámara de Diputados: cambios y continuidades en perspectiva histórica (1961-2010)", Documento de Trabajo ISCO, 8, año 2.

Dahl, R. A. (1961): Who governs? Democracy and power in an American city, Yale University Press, New Haven.

(1979): "A review of 'Who really rules? New Haven and community power reexamined'", Social Science Quarterly, 60, pp. 144-151.

Daloz, J. P. (2007): Elite distinction: grand theory and comparative perspectives, trabajo presentado en el Workshop "Recruitment and role perceptions of political elites in old and new democracies", University of Bamberg, Alemania, 23 de enero.

(2010): The sociology of élite distinction. From theoretical to comparative perspectives, Palgrave Macmillan, London.

Daviet-Vincent, M. (2004): “La prise en compte de plusieurs générations dans la méthode prosopographique: l'exemple des hauts fonctionnaires prussiens sous l'Empire et la république de Weimar", Genèses, 56, pp. 117-130.

Davis, J. (ed.) (2000): Identity and social change, Transaction Publishers, New Brunswick, NJ.

De Ramón, A. (1999): Biografías de chilenos. Miembros de los poderes ejecutivo, legislativo y judicial, Ediciones de la Pontificia Universidad Católica de Chile, Santiago.

Dézalay, Y. y B. Garth (2002): La mondialisation des guerres de palais. La restructuration du pouvoir d'Etat en Amérique Latine, entre notables du droit et 'Chicago Boys', Seuil, Paris.

Domhoff, G. W. (1990): The power élite and the state: how policy is made in America, Aldine de Gruyter, Hawthorne, NY.

(1996): State autonomy or class dominance? Case studies on policy making in America, Aldine de Gruyter, Hawthorne, NY.

(2002): "The power élite, public policy, and public opinion", en J. Manza, F. Cook y B. Page (eds.): Navigating public opinion: polls, policy, and the future of American democracy, Oxford University Press, New York, pp. 124-137.

(2003): Changing the powers that be: how the left can stop losing and win, Rowman and Littlefield, Lanham, MD.

(2005): "Who really ruled in Dahl's New Haven?", en http://www. whorulesamerica.net (2006 [1967]): Who rules America? Power, politics and political change (Fifth edition), McGraw-Hill, Boston, Mass. 
(2012): "How to do power structure research", en: http://www2.ucsc.edu/whorulesamerica/ methods/how to do power structure research.html\#Appendix A

Domínguez, J. (1997): Technopols. Freeing politics and markets in Latin America in the 1990s, The Pennsylvania State University Press-University Park, Pennsylvania.

Easterly, W. (2008): "Institutions: top down or bottom up?", American Economic Review: Papers \& Proceedings, 98 (2), pp. 95-99.

Espinoza, V. (2010): “Redes de poder y sociabilidad en la élite política chilena. Los parlamentarios 1990-2005", Polis, 9 (26), pp. 251-286.

Garrigou, A. (2001): Les élites contre la République. Sciences Po et l'ENA, La Découverte, Paris.

Gaxie, D. (1983): “Les facteurs sociaux de la carrière gouvernementale sous la Cinquième République de 1959 à 1981", Revue Française de Sociologie, 24 (3), pp. 441-465.

Gazmuri, C. (2001): "Notas sobre las élites chilenas, 1930-1999", Documento de Trabajo, 3, Instituto de Historia, Pontificia Universidad Católica de Chile.

Genieys, W. (2005): "The sociology of political elites in France: the end of an exception?", International Political Science Review, 26 (4), pp. 413-430.

Grantt, M. (1978): History of Rome (First edition), Prentice Hall, Englewood Cliffs, NJ.

Hall J. y R. Schroeder (eds.) (2005): An anatomy of power: the social theory of Michael Mann, Cambridge University Press, New York.

Hartmann, M. (2007): The sociology of elites, Routledge, London/New York.

Higley, J. (2008): Elite theory in political sociology, University of Texas at Austin.

Higley, J. y M. Burton (1989): "The élite variable in democratic transitions and breakdowns", American Sociological Review, 54 (1), pp. 17-32.

Higley, J. y R. Gunther (eds.) (1991): Elites and democratic consolidation in Latin America and Southern Europe, Cambridge University Press, New York.

Higley, J. y J. Pakulski (2000): "Jeux de pouvoir des élites et consolidation de la démocratie en Europe centrale et orientale", Revue Française de Science Politique, 50 (4), pp. 657-678.

Howe, H. (1978): "Max Weber's elective affinities", American Journal of Sociology, 84 (2), pp. 366-385

Huckfeldt R. y C. W. Kohfeld (1989): Race and the decline of class in American politics, University of Illinois Press, Chicago.

Hughes, T. (1993): Networks of power. Electrification in Western Society, 1880-1930 (Third edition), The Johns Hopkins University Press, Baltimore/London.

Hunter, F. (1953): Community power structure: a study of decision makers, University of North Carolina Press, Chapel Hill.

Joignant, A. (2009): "El estudio de las élites: un estado del arte", Documento de Trabajo, n¹, Serie de Políticas Públicas-Universidad Diego Portales.

(2011): "The politics of technopols: resources, political competence and collective leadership in Chile, 1990-2010", Journal of Latin American Studies, 43 (3), pp. 517-546.

Kadushin, C. (1995): "Friendship among the French financial élite", American Sociological Review, 60 (2), pp. 202-221.

Khan, S. (2012): Privilege: the making of an adolescent élite at St. Paul's School, Princeton University Press, New Jersey. 
Lane. D. (ed.) (2007): The transformations of State Socialism: system change, capitalism or something else?, Palgrave McMillan, London.

Lasswell, H. y A. Kaplan (1950): Power and society: a framework for political inquiry, Yale University Press, New Haven.

Levi, G. (1989): "Les usages de la biographie", Annales ESC, 44 (6), pp. 1325-1336.

Li, Y., A. Pickles y M. Savage (2005): "Social capital and social trust in Britain", European Sociological Review, 21 (2), pp. 109-123.

Linz, J. y A. Stepan (1996): "Hacia la consolidación democrática", La Política. Revista de Estudios sobre el Estado y Sociedad, 2, pp. 29-49.

Lipset, S. (1959): "Some social requisites of democracy: economic development and political legitimacy", American Political Science Review, 53 (1), pp. 69-105.

(1960): Political man: the social bases of politics, Doubleday Company, New York.

(1968): Revolution and counterrevolution: change and persistence in social structures, Basic Books, New York.

Lipset, S. y A. Solari (1967): Elites in Latin America, Oxford University Press, New York/London.

Mainwaring, S., D. Brinks y A. Pérez-Liñán (2001): "Classifying political regimes in Latin America, 1945-1999", Studies in Comparative International Development, 36 (1), pp. 37-65.

Mann, M. (1986): The sources of social power. A history of power from the beginning to A. D. 1760, Cambridge University Press, New York.

Markoff, J. y V. Montecinos (2001): "From the power of economic ideas to the power of economists", en M. A. Centeno y F. López-Alves (eds.): The other mirror. Grand theory through the lens of Latin America, Princeton University Press, New Jersey, pp. 105-150.

Mathiot, P. y F. Sawicki (1999): “Les membres des cabinets ministériels socialistes en France: recrutement et reconversion. 2) Passage en cabinet et trajectoires professionnelles", Revue Française de Science Politique, 49 (2), pp. 231-264.

Michels, R. (2001 [1915]): Political parties: a sociological study of the oligarchical tendencies of modern democracy, Batoche Books, Kitchener.

Moore, B. (1966): Social origins of dictatorship and democracy. Lord and peasant in the making of the Modern World, Beacon, Boston.

Morlino, L. (1989): "Consolidación democrática. Definición, modelo, hipótesis", Revista Uruguaya de Ciencia Política, 3, pp. 37-85.

Mosca, G. (1939 [1896]): The ruling class, Greenwood Press, Westport.

O'Donnell, G. y P. C. Schmitter (eds.) (1986): Transitions from authoritarian rule: tentative conclusions, John Hopkins University Press, Baltimore.

Pareto, V. (1991 [1901]): The rise and fall of the elites. An application of theoretical sociology, Transaction Publishers, New Brunswick, New Jersey.

Pitkin, H. (1967): The concept of representation, University of California Press, Berkeley.

PNUD (2004): Informe de Desarrollo Humano: El poder, ¿ para qué y para quién?, PNUD, Santiago.

Przeworski, A., M. Álvarez, J. A. Cheihub y F. Limongi (1997): "What makes democracies endure?", en Larry Diamond, Marc Plattner, Yun-Han Chu y Hung-Mao Tien: Consolidating the third wave democracies, John Hopkins University Press, Baltimore. 
Putnam, R. (1976): The comparative study of political elites, Prentice Hall, New Jersey.

(1977): "Elite transformation in advance industrial societies: an empirical assessment of the theory of technocracy", Comparative Political Studies, 10 (3), pp. 383-411.

Querubin, P. (2011): Political reform and élite persistence: term limits and political dynasties in the Philippines, Harvard Academy for International and Area Studies, en http://www.econ.yale. edu/conference/neudc11/papers/paper 242.pdf

Rossides, D. (1998): Social theory: its origins, history, and contemporary relevance, General Hall Inc., New York.

Schwartz, M. (ed.) (1987): The structure of power in America: the corporate élite as a ruling class, Holmes \& Meier, New York.

Scott, J. (2008): "Modes of power and the re-conceptualization of elites", Board of the Sociological Review, 56, Issue Supplement s1, pp. 25-43.

Silva P. (1991): "Technocrats and politics in Chile: from the Chicago Boys to the CIEPLAN Monks", Journal of Latin American Studies, 23 (2), pp. 385-410.

(2008): In the name of reason. Technocrats and politics in Chile, The Pennsylvania State University Press, Pennsylvania.

Skocpol, T. (1979): States and social revolutions: a comparative analysis of France, Russia and China, Cambridge University Press, New York.

Solimano, A. (2012): Chile and the neoliberal trap. The post-Pinochet era, Cambridge University Press, New York.

Suleiman, E. y H. Mendras (1995): Le recrutement des élites en Europe, La Découverte. Paris.

Thumala, M. (2008): Riqueza y piedad. El catolicismo de la élite económica chilena, Debate, Santiago.

Turchin, P. (2003): Historical dynamics: why states rise and fall, Princeton University Press, Princeton, NJ.

Valdés, J. G. (1995): Pinochet's economists: the Chicago School of Economics in Chile, Cambridge University Press, Cambridge.

Vanden, H. y G. Prevost (2002): Politics of Latin America. The power game, Oxford University Press, New York/London.

Weber, M. (1958): The protestant ethic and the spirit of capitalism, Scribner, New York. (1964): The theory of social and economic organization, The Free Press, New York.

(1978): Economy and society. An outline of interpretive sociology, University of California Press, Los Angeles/London.

Wright, E. O. (2005): "Foundations of a neo-Marxist class analysis", en E. O. Wright (ed.): Approaches to class analysis, Cambridge University Press, Cambridge.

Wright Mills, C. (1956): The power élite, Oxford University Press, New York/London.

Xiao, G. (2003): "The rise of technocrats", Journal of Democracy, 14 (1), pp. 60-65.

Zuckerman. A. (1977): "The concept political élite: lessons from Mosca and Pareto", The Journal of Politics, 39 (2), pp. 324-344. 